\title{
Frequency and distribution patterns of opportunistic infections associated with HIV/AIDS in Uganda
}

\author{
John Rubaihayo ${ }^{1,2^{*}}$, Nazarius M. Tumwesigye ${ }^{1}$, Joseph Konde-Lule ${ }^{1}$, Henry Wamani ${ }^{1}$, Edith Nakku-Joloba ${ }^{1}$ \\ and Fredrick Makumbi ${ }^{1}$
}

\begin{abstract}
Background: We conducted a study to assess the frequency and distribution patterns of selected opportunistic infections (Ols) and opportunistic cancers (OCs) in different geographical areas before and after HAART in Uganda.

Methods: This was a cross-sectional serial review of observation data for adult HIV positive patients ( $\geq 15$ years) enrolled with the AIDS support organization (TASO) in Uganda covering the period from January 2001 to December 2013. Both AIDS defining Ols/OCs and non-AIDS defining Ols were analyzed. The study period was structured into three time periods: "pre- HAART" (2001-2003), "early-HAART" (2004-2008) and "late-HAART" (2009-2013). Descriptive statistics were used to summarize the data by time period, age, gender and geographical location. Chi squared test used to test the significance of the differences in proportions.
\end{abstract}

Results: A total of 108,619 HIV positive patients were included in the analysis. $64 \%(64,240)$ were female with median age of 33 years (IQR 27-40). The most frequent Ols before HAART were oral candida (34.6\%) diarrhoeal infection (<1 month) (30.6\%), geohelminths (26.5\%), Mycobacterium tuberculosis (TB) (17.7\%), malaria (15.1\%) and bacterial pneumonia (11.2\%). In early HAART (2004-2008), the most frequent Ols were geohelminths (32.4\%), diarrhoeal infection (25.6\%), TB (18.2\%) and oral candida (18.1\%). In late HAART (2009-2013), the most frequent Ols were geohelminths (23.5\%) and diarrhoeal infection (14.3\%). By gender, prevalence was consistently higher in women $(p<0.05)$ before and after HAART for geohelminths, candidiasis, diarrhoeal infection, bacterial pneumonia and genital ulcer disease but consistently higher in men for TB and Kaposi's sarcoma $(p<0.05)$. By age, prevalence was consistently higher in older age groups ( $>30$ years) before and after HAART for oral candida and TB $(p<0.05)$ and higher in young age groups (<30 years) for malaria and genital ulcers $(p<0.05)$. By geographical location, prevalence was consistently higher in Eastern and Northern Uganda before and after HAART for diarrheal infection and geohelminths $(p<0.0001)$.

Conclusions: The frequency and pattern of Ols before and after HAART differs by gender, age and geographical location. Prevalence of geohelminths and diarrhea infection( $<1$ month) remains high especially in Northern and Eastern Uganda even after HAART and should therefore be given special attention in HIV/AIDS care programmes in these settings.

Keywords: HIV/AIDS, Opportunistic infections, Antiretroviral therapy, Prevalence, TASO, Uganda

\section{Background}

The human immunodeficiency virus (HIV) epidemic remains one of the greatest global health challenge of

\footnotetext{
*Correspondence: rubaihayoj@yahoo.co.uk

${ }^{2}$ Department of Public Health, School of Health Sciences, Mountains

of the Moon University, P.O. Box 837, Fort Portal, Uganda

Full list of author information is available at the end of the article
}

the 21st century [1] in the absence of an effective vaccine or curative therapy. According to the Joint United Nations Programme on HIV/AIDS (UNAIDS), 36.7 million people worldwide were estimated to be living with this deadly virus by end of 2015 of which 25.5 million (69.5\%) were in sub-Saharan Africa [1]. Since the outbreak of the HIV pandemic, an estimated 34 million 
people worldwide have died and sub-Saharan Africa accounts for almost $70 \%$ of the total deaths [2]. However, with increased access to highly active antiretroviral therapy (HAART), there has been tremendous improvement in survival and quality of life among persons living with HIV globally. Latest UNAIDS data shows by end of 2015, close to 17 million persons living with HIV globally were on HAART with subsequent reduction in mortality of $43 \%$ [1].

Opportunistic infections (OIs) associated with HIV remain the single main cause of ill-health and death among HIV/AIDS patients in resource poor settings [35]. OIs lower the quality of life of HIV infected persons, speeds up the rate of progression to fully blown AIDS, reduces patients' response to antiretroviral treatment especially when HIV-positive patients are co-infected with tuberculosis, increases stigma and limits one's ability to work and are usually associated with high medical care costs [6,7]. OIs have therefore greatly contributed to poverty among those infected and affected by HIV/ AIDS and hence an impediment to the attainment of the sustainable development goal (SDG) three on health in resource poor settings.

Although the natural history of HIV tends to be similar in most patients, the patterns of OIs that largely define the symptomatic and clinical manifestation of HIV infection tend to vary in different regions of the world $[4,8,9]$. Thus, while HIV patients in developed countries rarely suffer from bacterial and protozoal infections, they are a major cause of morbidity and mortality in resource-poor settings $[4,9,10]$. Though, the introduction of highly active antiretroviral therapy (HAART) has substantially reduced the risk of suffering from an opportunistic infection [11], HIV positive patients in resource poor settings continue to suffer from opportunistic infections due to several factors including late HIV diagnosis, sub-optimal HAART use, poor adherence, dug resistance, poverty, poor nutrition, high exposure to infectious agents, just to mention a few [10, 12-17].

Uganda is one of the few sub-Saharan countries in which the magnitude of the HIV epidemic has been substantially reduced and stabilized in the past decades; though recent reports show a slight increase in HIV prevalence among adults from a national average of $6.4 \%$ in 2005 to $7.3 \%$ in 2011 [18]. According to the Uganda AIDS indicator survey (2011), the burden of HIV varies by person (gender and age) and geographical area being predominantly higher in women $(8.3 \%)$ compared to men $(6.1 \%)$. By age, prevalence was found higher in older age groups ( $>35$ years) [18]. Geographically, the central region of Uganda was shown to have the highest HIV prevalence $(10.6 \%)$, followed by mid-northern (8.3\%) and then mid and south western (8-8.2\%) and lowest prevalence in mid-eastern (4.1\%) [18]. However, what was not clear was whether the burden of HIV related opportunistic infections follows the same pattern. The role of different OIs in morbidity before and after HAART has never been well documented. The purpose of this study was to assess the frequency, distribution patterns of different OIs before and after HAART in Uganda.

\section{Methods}

\section{Study setting}

The study obtained observational data from the AIDS support organization (TASO) known to be the oldest and largest HIV/AIDS care and treatment program in Uganda and sub-Saharan Africa. TASO was founded in 1987 and has 11 HIV/AIDS clinics spread across Uganda which have been nationally recognized as centres of excellence (CoE) in HIV/AIDS care and treatment in Uganda. TASO HIV clinics offer comprehensive HIV treatment and care, including provision of free antiretroviral drugs and cotrimoxazole prophylaxis, HIV testing and counselling, home-based care and psycho-social support to their clients. TASO HAART programme started as part of the National HAART roll-out programme in public health facilities in Uganda. Being one of the largest HAART providers in the country, TASO attracted a lot of support from different funders supporting HAART programmes in sub-Saharan Africa including the President's Emergency Plan for AIDS Relief (PEPFAR) and the Global Fund to Fight AIDS, Tuberculosis and Malaria. Initially, HAART eligibility was based on WHO 2006 guidelines i.e. WHO stage 3 or 4 illness or a CD4 cell count $<200$ cells $/ \mu \mathrm{l}$ for adults and adolescents and WHO stage III, advanced stage II or stage I with CD4 cell percentage less than $20 \%$ for those more than 18 months of age [20]. However, in 2010 new HAART guidelines [21] that raised the threshold for adults and adolescents to a CD4 cell count $\leq 350$ or WHO clinical stage 3 or 4 irrespective of CD4 cell count were adopted [22]. Those not eligible for HAART were offered cotrimoxazole or dapsone prophylaxis. Additionally TASO HAART delivery includes community volunteers/treatment partners that help to monitor HAART adherence, adverse effects, opportunistic infections and reporting those who die. All services are free of charge including anti-retroviral drugs (ARVs) for those who are eligible [23].

\section{Study design}

This was a serial cross-sectional review of observation data for adult HIV positive patients ( $\geq 15$ years) obtaining care and treatment from the AIDS support organization (TASO) in Uganda covering the period from 1st January 2001 to 31st December 2013. A total of 17 opportunistic infections including 14 AIDS-defining opportunistic 
infections (Oral candida, Esophageal candida, Mycobacterium tuberculosis, Genital ulcer disease, Cryptococcal meningitis, Herpes zoster, Bacterial pneumonia, Diarrhoeal infection $<1$ month, Cryptosporidiosis, Herpes simplex labialis, Cytomegalovirus, Toxoplasmosis, Pneumocystis jiroveci pneumonia, Oral hairy leukoplakia), one opportunistic cancer (Kaposis sarcoma) and three non-AIDS defining opportunistic infections (Malaria and Geoheminths) were the main focus of this study. The study time was structured into three time periods corresponding to two important milestones in HIV care and treatment in Uganda. The first time period was designated as "pre-HAART" (2001-2003) when HAART was not available. The second time period was designated as "early HAART" (2004-2008) when HAART access was limited to only severely ill patients (CD4 count $\leq 200$ cells/ $\mu \mathrm{l}$ regardless of clinical stage or WHO stage III or IV disease) $[19,20]$. The third time period was designated as "late HAART" (2009-2013) when HAART access was expanded to include patients with CD4 cell count $>200$ cells $/ \mu$ l but $\leq 350$ cells $/ \mu$ or had WHO stage III or IV disease regardless of CD4 cell count [21].

\section{Sampling and sample size}

Four TASO HIV clinics were purposively selected basing on volume and quality of data available and geographical representation. The HIV clinics selected were TASO Mulago HIV clinic in central Uganda, TASO Mbarara HIV clinic in south-western Uganda, TASO Tororo HIV clinic in Eastern Uganda and TASO Gulu HIV clinic in Northern Uganda (Fig. 1). All HIV positive adults (15 years and above) who attended at least once at the selected HIV clinics in the period from 1st January 2001 to 31 st December 2013 were included in the study.

\section{Data collection}

TASO medical staff systematically registered the clients' demographic characteristics and medical information following an established protocol for all TASO HIV clinics. In brief, clients were expected to attend the clinic at least once a month. At each clinic visit, data per client was collected on a standardized case report form (CRF) detailing the client's demographic information, clinical condition, medical history, OI diagnosis, ART use, prophylaxis use, any other treatment given and side effects/toxicities if any. OI diagnosis was based on WHO and Uganda ministry of Health guidelines [20-22, 24]. Data were then compiled and entered into the TASO electronic data base by TASO data administrator using EPINFO vs3 in Access format. Monthly medical data for each participant covering the period January 2001 to December 2013 were extracted by the data administrator, delinked from overt identifiers and then handed over for analysis.

\section{Data analysis}

The extracted data were analyzed using Stata statistical software version 13.1 (Stata Corp, College station, Texas, USA). Descriptive statistics were summarized by frequencies and percentages. For categorical variables, Chi squared test was used to test for the differences in proportions and Wilcoxon rank-sum test for metric variables. Prevalence was calculated from the number patients ever diagnosed with a particular OI divided by the total number of patients who attended monthly clinic visits at least once in a given period. All significance tests were two sided with a p value $<0.05$ considered significant.

\section{Results}

Socio-demographic and baseline clinical characteristics

A total of 108,619 HIV positive individuals were included in the analysis of which $64 \%$ were female with median age of 33 years (IQR 27-40). Majority were subsistence farmers $(83 \%)$ with primary or no education $(77 \%)$, largest number were married (47\%) and were Catholics by religion/faith (45\%) (Table 1). Gulu HIV clinic in Northern Uganda had the largest number of Catholics (73\%) While Mbarara HIV clinic in Western Uganda had the largest number of Protestants (51\%). Tororo HIV clinic in Eastern Uganda had the largest number of marrieds (54\%). Mulago HIV clinic in Central Uganda had the largest number of divorcees (27\%), highly educated (>secondary) (34\%) and fewer subsistence farmers (18\%).

\section{Frequency and distribution patterns of Ols}

Opportunistic infections (OIs) accounted for 99\% of morbidity causes compared to $1 \%$ due to opportunistic cancers (Kaposi's sarcoma, Burkitti's lymphoma and Malignant melanoma). Overall, from 2001 to 2013, a total of 291,168 OI episodes were recorded mainly caused by 16 opportunistic infections and Kaposi's sarcoma which though not an opportunistic infection but was included because of its infectious cause (human herpes virus type 8) [25]. Overall the burden of OIs was largely due to geohelminths $(30.7 \%)$, diarrhoeal infection $<1$ month (25.5\%), oral candida (19.4\%), M. tuberculosis (18.3\%), bacterial pneumonia (14.8\%) and genital ulcers (10\%), others were below $10 \%$ (Table 2).

Before HAART (2001-2003), the most frequent OIs were oral candida (34.6\%) diarrhoea $<1$ month $(30.6 \%)$, geohelminths (26.5\%), M. tuberculosis (17.7\%), malaria (15.1\%) and bacterial pneumonia (11.2\%), the rest were below $10 \%$. In early HAART (2004-2008), the most frequent OIS (>10\%) were geohelminths (32.4\%), diarrhoea $<1$ month (25.6\%), M. tuberculosis (18.2\%) and oral candida (18.1\%). In late HAART (2009-2013), the most frequent OIs (>10\%) were geohelminths $(23.5 \%)$ and diarrhoea $<1$ month (14.3\%) (Fig. 2). 


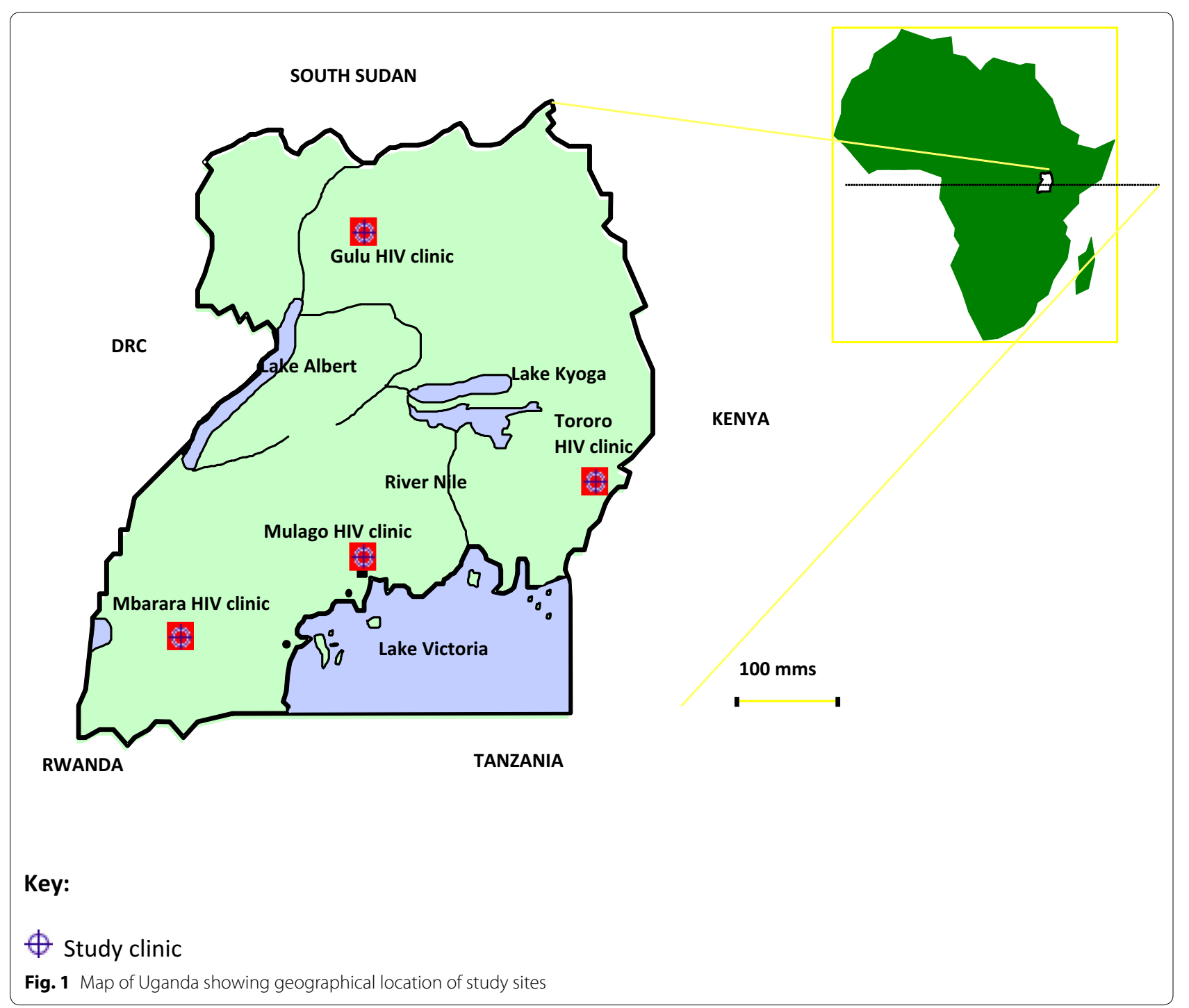

By gender, prevalence was greater in women for most OIs except for M. tuberculosis and Kaposi's sarcoma (Table 3). By age, prevalence was generally higher in older age groups ( $>30$ years) for most OIs except malaria and genital ulcers which were predominantly higher in younger age groups $[<30$ years (Table 4 )]

By geographical location, highest prevalence before HAART was observed in Tororo HIV clinic in Eastern Uganda for diarrhea $<1$ month (43.1\%), geohelminths (40.9\%) and TB (12.7\%); Mbarara HIV clinic in Southwestern Uganda for oral candida (43.1\%) and malaria (16.7); Mulago HIV clinic in Central Uganda for genital ulcers (12.6\%). In Early HAART, highest prevalence was observed: in Gulu HIV clinic in Northern Uganda for geohelminths (37.7\%), diarrhea $<1$ month $(36.8 \%)$, TB (21.0\%) and malaria (10.6\%); in Mbarara HIV clinic in South-western Uganda for oral candida (24\%) and
Mulago HIV clinic in Central Uganda for genital ulcers (12.6\%). In late HAART, highest prevalence was observed in Gulu HIV clinic in Northern Uganda for geohelminths (26.3\%) and Tororo HIV clinic in Eastern Uganda for diarrhea $<1$ month (19.0\%) (Table 5).

\section{Discussion}

The study summaries clinical data representing nearly 7\% (108,619/1.6 million) of Ugandans living with HIV/ AIDS. Majority were women (64\%), with low education (primary or none) (77\%) and of very low socio-economic status (venders/petty traders/subsistence farmers) (76\%). This nature of patients is comparable to other HIV positive patients found elsewhere in ART programmes in sub-Saharan Africa [17, 26-28]. A study in Nigeria, in which both pre-HAART and post-HAART data for HIV positive patients in care were analyzed, $65.8 \%$ were 
Table 1 Demographic characteristics of the study participants, total and clinic-specific

\begin{tabular}{|c|c|c|c|c|c|}
\hline Variable & $\begin{array}{l}\text { Total number } \\
\mathrm{n}(\%)\end{array}$ & $\begin{array}{l}\text { Tororo HIV clinic } \\
\mathrm{n}(\%)\end{array}$ & $\begin{array}{l}\text { Mulago HIV clinic } \\
\text { n (\%) }\end{array}$ & $\begin{array}{l}\text { Mbarara HIV clinic } \\
\text { n (\%) }\end{array}$ & $\begin{array}{l}\text { Gulu HIV clinic } \\
\text { n (\%) }\end{array}$ \\
\hline \multicolumn{6}{|l|}{ Gender $(n=108,619)$} \\
\hline Female & $69,240(64)$ & $16,458(62)$ & $21,498(67)$ & $19,350(63)$ & $11,934(62)$ \\
\hline Male & $39,379(36)$ & $9966(38)$ & $10,803(33)$ & $11,433(37)$ & 7177 (38) \\
\hline Median age $(\mathrm{IQR})(\mathrm{n}=107,112)$ & $33(27,40)$ & $34(28,41)$ & $33(27,40)$ & $33(27,40)$ & $33(26,40)$ \\
\hline \multicolumn{6}{|l|}{ Occupation $(n=86,136)$} \\
\hline Paid employee & $15,061(17)$ & $2337(11)$ & $6613(27)$ & $2929(13)$ & $3182(18)$ \\
\hline Self employed & $31,073(36)$ & $6905(32)$ & $10,975(46)$ & $5516(24)$ & $7677(43)$ \\
\hline Subsistence farmer & $34,564(40)$ & $11,250(52)$ & $4390(18)$ & $12,635(56)$ & $6289(35)$ \\
\hline Others & $5438(6)$ & $1105(5)$ & $2075(9)$ & $1485(7)$ & $773(4)$ \\
\hline \multicolumn{6}{|l|}{ Education $(n=92,840)$} \\
\hline None & $19,712(21)$ & $6009(28)$ & $2672(11)$ & $6258(21)$ & $4773(27)$ \\
\hline Primary & $51,768(56)$ & $11,768(54)$ & $13,136(55)$ & $17,046(58)$ & $9818(55)$ \\
\hline Secondary & $17,908(19)$ & $3236(15)$ & $6831(28)$ & $5102(17)$ & $2739(15)$ \\
\hline Tertiary or above & $3452(4)$ & $640(3)$ & $1376(6)$ & $855(3)$ & $581(3)$ \\
\hline \multicolumn{6}{|l|}{ Marital status $(n=93,004)$} \\
\hline Single/never married & $5747(6)$ & $1587(7)$ & $1652(7)$ & $1816(6)$ & $692(4)$ \\
\hline Married/cohabiting & $43,661(47)$ & $11,600(54)$ & $10,203(42)$ & $13,369(45)$ & $8489(47)$ \\
\hline Divorced & $17,138(18)$ & $2783(13)$ & $6409(27)$ & $4802(16)$ & $3144(17)$ \\
\hline Widowed & $21,698(23)$ & $4923(23)$ & $4739(20)$ & $7535(26)$ & $4501(25)$ \\
\hline Others & $4760(5)$ & $701(3)$ & $1034(4)$ & $1897(6)$ & $1128(6)$ \\
\hline \multicolumn{6}{|l|}{ Religion/faith $(n=91,826)$} \\
\hline Catholic & $41,772(45)$ & $9169(42)$ & $9022(38)$ & $10,604(37)$ & $12,977(73)$ \\
\hline Protestant & $33,171(36)$ & $7166(33)$ & $8290(34)$ & $14,642(51)$ & $3073(17)$ \\
\hline Muslim & $7114(8)$ & $1740(8)$ & $3288(14)$ & $1627(6)$ & $459(3)$ \\
\hline Pentecostal & $6835(7)$ & $2440(11)$ & $2536(11)$ & $874(3)$ & $985(5)$ \\
\hline Others & $2934(3)$ & $1078(5)$ & $840(3)$ & $698(2)$ & $318(2)$ \\
\hline
\end{tabular}

found to be women and more than half (50.4\%) were of low socio-economic status [28]. Another study that examined data from an ART cohort in a rural hospital in western Uganda also found $65.3 \%$ of the beneficiaries were women and $77.4 \%$ were of low socio-economic class (unemployed/self-employed/subsistence farmers) [26]. The fact that there were twice as many women than men in the current study is additional evidence that men remain under-represented in most ART programmes in sub-Saharan Africa with consequently less favourable programme outcomes.

Overall, opportunistic infections (OIs) occurred most and accounted for $99 \%$ of all opportunistic events compared to $1 \%$ due to opportunistic cancers (Kaposi's sarcoma, malignant melanomas, Burkitt's lymphoma and other lymphomas). This is also additional evidence that opportunistic infections as opposed to opportunistic cancers are the primary cause of morbidity and mortality among HIV positive individuals in sub-Saharan Africa [6]. Histoplasmosis, Mycobacterium avium complex were not seen in the current study providing additional evidence that these OIs might be absent or there is lack of diagnostic capacity in sub-Saharan Africa [29, 30]. The apparent rarity of Cytomegalovirus, Pneumocystis jiroveci pneumonia, Cryptosporidiosis and Toxoplasmosis in the current study could also be due to lack of diagnostic capacity or evidence that they are rare among African HIV positive patients. The low prevalence of Cryptococcal meningitis (CM) and Kaposi's sarcoma (KS) could perhaps be due to the fact that TASO HIV clinics being mainly out-patient clinics and CM and KS being referral conditions, cases may have opted to seek for specialized care elsewhere. However, even other studies elsewhere in sub-Saharan Africa have shown low prevalence of both CM and KS. For example a study in Nigeria found prevalence of $\mathrm{CM}$ and $\mathrm{KS}$ was relatively lower at 0.6 and $0.3 \%$ respectively compared to candidiasis $(8.6 \%)$ and $\mathrm{TB}$ (7.7\%) [28].

Before HAART (2001-2003) the burden of OIs, as expected, was indeed very high. The most common OIs before HAART were oral candida (34.6\%), diarrhoeal <1 month (30.6\%), geohelminths (26.5\%), $M$. 
Table 2 Overall frequency distribution of different types of Ols among HIV positive patients in TASO, Uganda (2001-2013)

\begin{tabular}{llc}
\hline & \multicolumn{2}{l}{ Overall (2001-2013) } \\
\cline { 2 - 3 } & $\begin{array}{l}\text { Frequency } \\
\text { (n=108,619) }\end{array}$ & Percent $^{\mathbf{a}}$ \\
\hline Opportunistic infection & & \\
Geo helminthes & 33,311 & 30.7 \\
Diarrhea $<1$ month & 27,658 & 25.5 \\
Oral candida & 21,053 & 19.4 \\
Mycobacterium tuberculosis & 19,825 & 18.3 \\
Bacterial pneumonia & 16,076 & 14.8 \\
Genital ulcer & 10,887 & 10.0 \\
Confirmed malaria & 8924 & 8.2 \\
Esophageal candida & 8778 & 8.0 \\
Herpes zoster & 7113 & 6.5 \\
Cryptosporidiosis & 3551 & 3.3 \\
Cryptococcosis & 1725 & 1.6 \\
Herpes simplex labialis & 1367 & 1.3 \\
Cytomegalovirus & 616 & 0.6 \\
Toxoplasmosis & 589 & 0.5 \\
Pneumocystis carini/jiroveci pneumonia & 374 & 0.3 \\
Oral hairy leukoplakia & 360 & 0.3 \\
Hepatitis B or C virus & 303 & 0.3 \\
Opportunistic cancer & & \\
Kaposis sarcoma/HHV8 & 1155 & 1.1 \\
\hline HH8 & & \\
\hline
\end{tabular}

HHV8 human herpes virus type $8, n$ number of patients

a Proportion of study participants ever diagnosed with a particular $\mathrm{Ol}$ in the period 2001-2013

tuberculosis (17.7\%), malaria (15.1\%) and bacterial pneumonia (11.2\%). This might be because they are highly endemic in the country and easy to diagnose. The most frequent OIs after HAART (late HAART) were diarrhoea $<1$ month and geohelminths. Similar OIs were also observation in other previous studies in African settings $[17,28,31,32]$.

In the current study, oral candidiasis was the most frequent opportunistic infection before HAART. According to Staine [6], oral candida caused by the fungus Candida albicans has been associated with HIV infection ever since HIV/AIDS was first reported in early 1980s [6]. In some studies in developed countries, the prevalence of oral candidiasis was as high as $44.8 \%$ in USA [9] and $23 \%$ in France [33] before HAART was introduced. A review of studies on HIV/AIDS related opportunistic infections in sub-Saharan Africa, showed the prevalence of oral candidiasis ranged from 14\% in HIV infected pregnant women attending a rural hospital in Cameroon [34] to $67 \%$ among Senegalese in patients with AIDS [35] before HAART. However, most studies in the HAART era, show that it's prevalence has reduced but is still common among HIV infected persons [15, 36-38]. In Uganda, most studies before HAART reported high prevalence of oral candidiasis among HIV-infected persons [39-41]. In the current study we have found that the prevalence of oral candida has substantially reduced though not completely eliminated probably because it is endemic in the country and common even among those who are not HIV positive. The risk for oral was higher in women and with old age but varied by geographical area being more common in Mbarara in South-western Uganda. The reasons for these geographical differences require further investigations.

In the current study, diarrhea $<1$ month was most frequent OI before and after HAART. Previous studies show up to $60 \%$ of people living with HIV experience diarrhoea, that negatively affects their quality of life and adherence to HAART [42]. Diarrhoea among HIV positive individuals may be due to multiple causes including infectious causes (bacterial, viral, protozoal, helminthic, etc.) or non-infectious causes(ARV drug effects e.g. ritonavir-boosted protease inhibitors such as lopinavir/ritonavir or nelfinavir) [42-46]. In Uganda, a previous study reported the commonest causes of diarrhoea to be helminthic infections (29.5\%), bacterial infections (19.2\%) and protozoal infections (9.2\%) [47]. In the current study we found diarrhoea $<1$ months was more common among women compared to men probably because women by nature of their traditional responsibilities tend to be more vulnerable than men. Prevalence of diarrhea $<1$ month was found higher among HIV positive patients at Gulu HIV clinic in Northern and Tororo HIV clinic in Eastern Uganda compare to HIV positive patients at Mulago HIV clinic in Central Uganda and Mbarara HIV clinic in South-western Uganda probably because of the socio-economic disparities between these regions with the later being relatively more developed compared to the former. Though preventable, the persistence of diarrhoea $<1$ month after HAART and free access to universal antimicrobial prophylaxis needs further investigations to establish the actual cause.

TB caused by $M$. tuberculosis is one of the leading causes of morbidity and mortality in persons infected with HIV/AIDS globally [48]. Studies show that HIV reactivates latent TB hence increasing the risk of TB in HIV-infected patients [49]. In 2012, about $13 \%$ of the people who developed TB globally were HIV positive and the prevalence of TB co-infection was highest in subsaharan Africa [48]. In the current study, TB was among the most frequent OIs especially in the period before HAART and prevalence was higher in men compared to women. The sex difference is consistent with many other previous studies which show men were more at risk of suffering from TB compared to women [50,51]. 
B efore HAART (2001-2003)

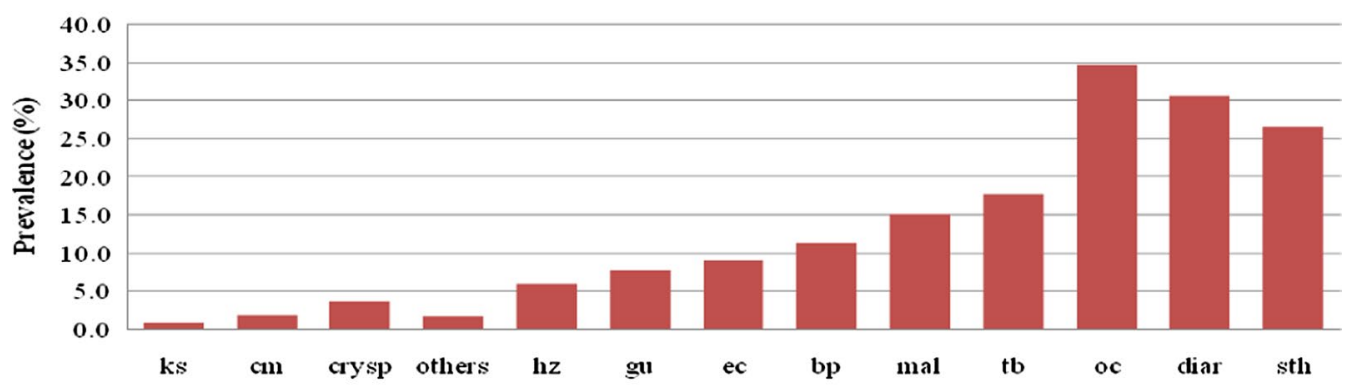

Early HAART (2004-2008)

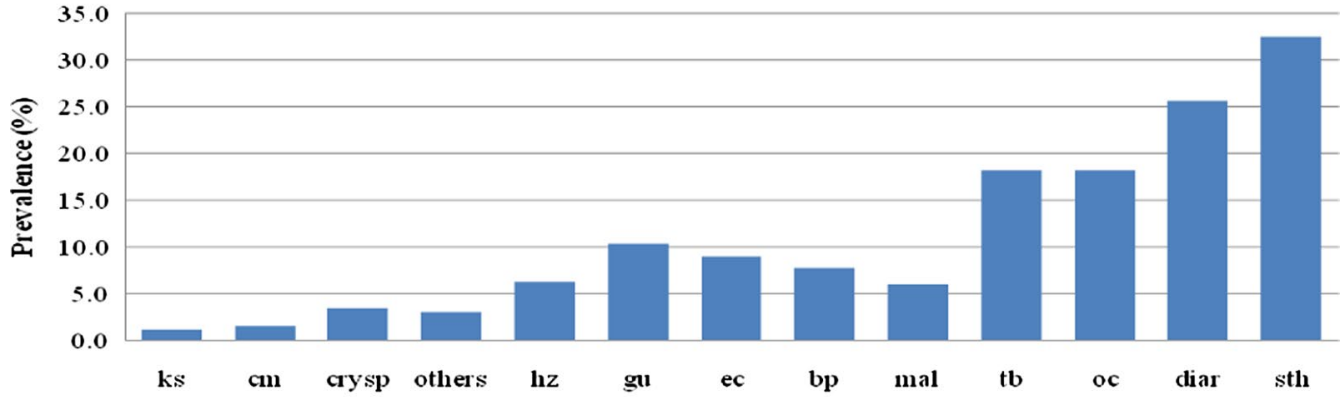

Late HAART (2009-2013)

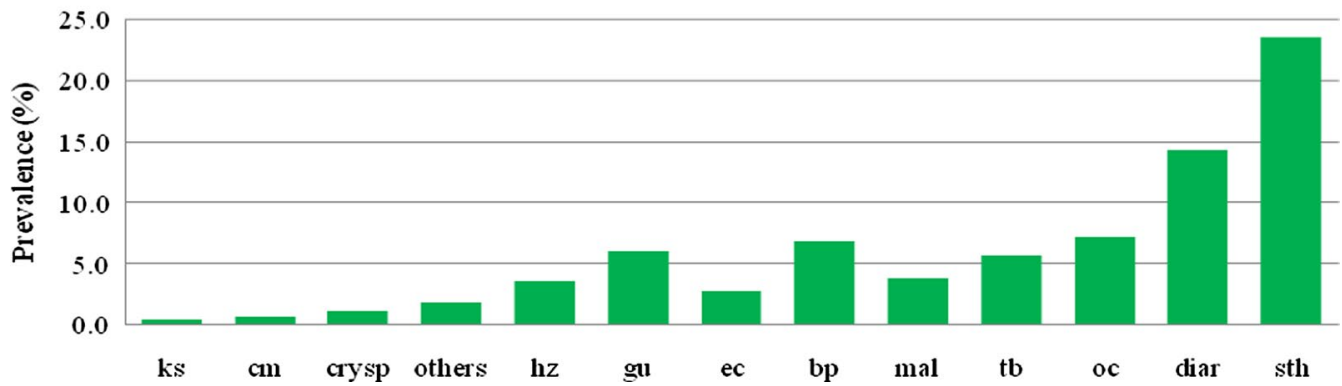

Fig. 2 Bar charts showing period prevalence of selected Ols among HIV positive patients in TASO, Uganda before HAART, early and late HAART. sth soil transmitted helminthes, diar diarrhea, cm cryptococcal meningitis, ec esophageal candida, tb tuberculosis, oc oral candida, bp bacterial pneumonia, gu genital ulcer, ks Kaposis sarcoma, crysp cryptosporidiosis, hz herpes zoster, mal malaria, others (Herpes simplex labialis, Toxoplasmosis, Cytomegalovirus, Pneumocystis carinii/jiroveci pneumonia)

The reason for this increased risk in men could probably be attributed to delayed enrolment on HAART by men compared to women [26]. In the current study it was also observed that TB was more frequent among HIV positive patients in Northern and Eastern Uganda compared to other geographical areas probably because of the socioeconomic disparities in the regions. Previous studies show that poverty was a strong predictor of OIs even in the era of HAART $[28,52]$. Generally TB prevalence was higher in older age groups ( $>30$ years) which is consistent with other previous studies that shows TB prevalence increases with age [53]. A WHO TB prevalence survey 2014 in Indonesia found that TB prevalence was almost five times higher in older age groups ( $>40$ years) compared to younger groups in both sexes [53].

Bacterial pneumonia (BP) caused by Streptococcus pneumoniae is one of the commonest respiratory tract infections in persons living with HIV/AIDS [4, 54-57]. A review of studies on HIV/AIDS related opportunistic infections in sub-Saharan Africa show high prevalence of S. pneumonia infection ranging from $25 \%$ in Cameroon to $31 \%$ in Uganda [4]. In our study, bacterial pneumonia was one of the commonly encountered opportunistic infection with an overall period prevalence of $14.8 \%$. However its prevalence varied by geographical area with highest prevalence in Eastern Uganda. We also found BP 
Table 3 Chi squared test for the difference in OI prevalence by gender before and after HAART

\begin{tabular}{|c|c|c|c|}
\hline & \multicolumn{2}{|l|}{ Prevalence } & \multirow[t]{2}{*}{$p$ value } \\
\hline & Women $(n=16,519), n(\%)$ & Men $(n=7848), n(\%)$ & \\
\hline \multicolumn{4}{|l|}{ Before HAART (2001-2003) } \\
\hline \multicolumn{4}{|l|}{ Opportunistic infection } \\
\hline Oral candida & $5987(36.2)$ & $2449(31.2)$ & $<0.0001$ \\
\hline Diarrhoea & $5164(31.3)$ & $2295(29.2)$ & $<0.0001$ \\
\hline Geohelminths & $4544(27.5)$ & $1912(24.4)$ & $<0.0001$ \\
\hline Mycobacterium tuberculosis & $2769(16.8)$ & $1544(19.7)$ & $<0.0001$ \\
\hline Confirmed malaria & $2582(15.6)$ & $1087(13.9)$ & $<0.0001$ \\
\hline Bacterial pneumonia & $1928(11.7)$ & $809(10.3)$ & $<0.0001$ \\
\hline Esoph candida & $1620(9.8)$ & $567(7.2)$ & $<0.0001$ \\
\hline Genital ulcer & $1430(8.7)$ & $433(5.5)$ & $<0.0001$ \\
\hline Herpes zoster & $1011(6.1)$ & $418(5.3)$ & 0.025 \\
\hline Cryptosporidiosis & $624(3.8)$ & $271(3.5)$ & 0.076 \\
\hline Cryptococcosis & $275(1.7)$ & $152(1.9)$ & 0.702 \\
\hline Others & $301(1.8)$ & $90(1.1)$ & 0.019 \\
\hline \multicolumn{4}{|l|}{ Opportunistic cancer } \\
\hline \multirow[t]{3}{*}{ Kaposi's sarcoma/HHV8 } & $114(0.7)$ & $95(1.2)$ & 0.068 \\
\hline & \multicolumn{2}{|l|}{ Prevalence } & \multirow[t]{2}{*}{ p value } \\
\hline & Women ( $n=38,599), n(\%)$ & Men $(n=20,232), n(\%)$ & \\
\hline \multicolumn{4}{|l|}{ Early HAART (2004-2008) } \\
\hline \multicolumn{4}{|l|}{ Opportunistic infection } \\
\hline Geohelminths & $13,205(34.2)$ & $5858(29.0)$ & $<0.0001$ \\
\hline Diarrhoea & $10,231(26.5)$ & $4812(23.8)$ & $<0.0001$ \\
\hline Oral candida & $7710(20.0)$ & $2961(14.6)$ & $<0.0001$ \\
\hline Mycobacterium tuberculosis & 3419 (16.9) & $7262(18.8)$ & $<0.0001$ \\
\hline Bacterial pneumonia & $1741(8.6)$ & $2839(7.4)$ & $<0.0001$ \\
\hline Genital ulcer & $4461(11.6)$ & $1660(8.2)$ & $<0.0001$ \\
\hline Esoph candida & $3872(10.0)$ & $1456(7.2)$ & $<0.0001$ \\
\hline Confirmed malaria & $2482(6.4)$ & $1111(5.5)$ & 0.023 \\
\hline Herpes zoster & $2606(6.8)$ & $1152(5.7)$ & 0.037 \\
\hline Cryptosporidiosis & $1373(3.6)$ & $662(3.3)$ & 0.061 \\
\hline Cryptococcosis & $602(1.6)$ & $332(1.6)$ & 0.097 \\
\hline Others & $1260(3.3)$ & $539(2.7)$ & 0.06 \\
\hline \multicolumn{4}{|l|}{ Opportunistic cancer } \\
\hline \multirow[t]{3}{*}{ Kaposi's sarcoma/HHV8 } & $347(0.9)$ & $330(1.6)$ & 0.012 \\
\hline & \multicolumn{2}{|l|}{ Prevalence } & \multirow[t]{2}{*}{$p$ value } \\
\hline & Women ( $n=40,335), n(\%)$ & Men $(n=22,547), n(\%)$ & \\
\hline \multicolumn{4}{|l|}{ Late HAART (2009-2011) } \\
\hline \multicolumn{4}{|l|}{ Opportunistic infection } \\
\hline Geohelminths & $9951(24.7)$ & $4852(21.5)$ & $<0.0001$ \\
\hline Diarrhoea & $6056(15.0)$ & 2917 (12.9) & $<0.0001$ \\
\hline Oral candida & $3063(7.6)$ & $1446(6.4)$ & 0.029 \\
\hline Bacterial pneumonia & $2895(7.2)$ & $1453(6.4)$ & 0.045 \\
\hline Genital ulcer & $2581(6.4)$ & $1202(5.3)$ & 0.017 \\
\hline Mycobacterium tuberculosis & $2101(5.2)$ & $1489(6.6)$ & 0.024 \\
\hline Confirmed malaria & $1595(4.0)$ & $789(3.5)$ & 0.540 \\
\hline Herpes zoster & $1522(3.8)$ & $748(3.3)$ & 0.490 \\
\hline
\end{tabular}


Table 3 continued

\begin{tabular}{|c|c|c|c|}
\hline & \multicolumn{2}{|l|}{ Prevalence } & \multirow[t]{2}{*}{$\mathrm{p}$ value } \\
\hline & Women $(n=40,335), n(\%)$ & Men $(n=22,547), n(\%)$ & \\
\hline Esoph candida & $1163(2.9)$ & $594(2.6)$ & 0.046 \\
\hline Cryptosporidiosis & $464(1.2)$ & $231(1.0)$ & 0.792 \\
\hline Cryptococcosis & $251(0.6)$ & $166(0.7)$ & 0.09 \\
\hline Others & $759(1.9)$ & $390(1.7)$ & 0.102 \\
\hline \multicolumn{4}{|l|}{ Opportunistic cancer } \\
\hline Kaposi's sarcoma/HHV8 & $150(0.4)$ & $160(0.7)$ & 0.015 \\
\hline
\end{tabular}

HHV8 human herpes virus $8, n$ number of patients

was less in the period after HAART (2009-2013) at 8\% compared to the period before HAART (13\%) probably due to increased access to HAART and universal cotrimoxazole prophylaxis. Though a conjugate pneumococcal vaccine $[54,56]$ is now available in Uganda but it is still under limited access and we recommend that it should be availed to all HIV positive patients so as to reduce on the burden of bacterial pneumonia. It may be possible that bacterial pneumonia could have been under reported as in some cases, data were recorded as respiratory tract infection without specifying the infection.

In this study both AIDS defining and non-AIDS defining OIs were considered. Non-AIDS defining OIs found common among HIV positive patients in these settings were malaria and geohelminths. Given the geographical overlap of malaria and geohelminths with HIV in subSaharan Africa, there is great concern of the increasing number of helminthic and malaria co-infections among HIV positive patients [58-61]. Although malaria is not among the WHO defined opportunistic infections diagnostic of AIDS [62], several studies show that malaria tends to occur with increased frequency and severity in advanced HIV-infected adults [4, 63-68]. This happens probably because HIV infection reduces resistance to malaria by compromising the immune system. In our study we found malaria was very common among HIV positive patients especially before HAART consistent with previous studies elsewhere [4, 66-68]. According to the World Malaria Report 2014, Uganda was ranked 3rd after Democratic republic of Congo and Nigeria in contribution to the global burden of malaria [69]. Previous studies on malaria and HIV show that HIV increases vulnerability to malaria infection and malaria could enhance the progression of HIV infection to clinical AIDS in the absence of effective treatment $[59,70]$.

In the current study, prevalence of malaria men were less likely to suffer from malaria compared to women and the risk was less in those $>35$ years of age and varied by geographical area with the western Uganda having the highest risk compared to other geographical areas.
Higher prevalence of malaria in younger age groups is consistent with previous findings that showed malaria prevalence to be inversely related with age [71-73]. Geographical variation in prevalence could be influenced by malaria endemicity in the different geographical areas.

Though malaria prevalence among HIV positive patients reduced in the era of HAART, it has not been completely eliminated. In view of the fact that malaria is highly endemic in Uganda and HIV positive patients are highly vulnerable, malaria prevention/control should therefore remain an integral part of comprehensive HIV/ AIDS care in Uganda.

In the current study, geohelminths were the most commonly observed opportunistic infections among HIV positive patients before and after HAART. This is consistent with other studies elsewhere in resource poor settings. A study in Tanzania that investigated HIV and parasitic co-infections among HIV positive patients seeking care and treatment at health facilities in Tanzania found $22.1 \%$ had helminthic infections (hookworms, Strongyloides stercoralis, Ascaris lumbricoides, schistosomes), $12.9 \%$ had malaria and $13 \%$ had both [74]. A related study in Rwanda that investigated the prevalence of soil transmitted helminthes and malaria among HIV positive pregnant women attending antenatal health centers in Rwanda found 38\% had helminthic infections (A. lumbricoides, Trichuris trichiura, Ancylostoma duodenale and Necator americanus), $21 \%$ had malaria and $10 \%$ had both [61]. Though geohelminths are not AIDSdefining opportunistic infections, previous studies show that co-infection with geohelminths was associated with dysregulation of the immune response causing inability of the HIV positive patient to mount an effective immune response [75]. High prevalence of geohelminths can lead to increased prevalence of anaemia thereby worsening the health conditions of persons living with HIV/ AIDS [76]. Geohelminths have also been associated with diarrhea, nutritional impairment, abdominal pain and in children they can lead to impaired cognitive and physical development [58]. They have also been shown to 
Table 4 Chi squared test for the difference in OI prevalence by age at enrolment before and after HAART

\begin{tabular}{|c|c|c|c|c|}
\hline & \multicolumn{3}{|l|}{ Prevalence } & \multirow[t]{2}{*}{$p$ value } \\
\hline & Age $<30(n=8070), n(\%)$ & Age $=30-39(n=10,008), n(\%)$ & Age $\geq 40(n=6223), n(\%)$ & \\
\hline \multicolumn{5}{|l|}{ Before HAART (2001-2003) } \\
\hline \multicolumn{5}{|l|}{ Opportunistic infection } \\
\hline Geohelminths & $2187(27.1)$ & $2536(25.3)$ & $1714(27.5)$ & 0.058 \\
\hline Diarrhoea & $2422(30.0)$ & $3117(31.1)$ & 1907 (30.6) & 0.671 \\
\hline Oral candida & $2586(32.0)$ & $3625(36.2)$ & $2213(35.6)$ & $<0.001$ \\
\hline Mycobacterium tuberculosis & $1350(16.7)$ & $1706(17.0)$ & $1251(20.1)$ & 0.031 \\
\hline Bacterial pneumonia & $905(11.2)$ & $1113(11.1)$ & $706(11.3)$ & 0.139 \\
\hline Genital ulcer & $667(8.3)$ & $802(8.0)$ & $390(6.3)$ & 0.026 \\
\hline Confirmed malaria & $1277(15.8)$ & $1518(15.2)$ & $863(13.9)$ & 0.029 \\
\hline Esoph candida & $654(8.1)$ & $945(9.4)$ & $585(9.4)$ & 0.126 \\
\hline Herpes zoster & $505(6.3)$ & $568(5.7)$ & $351(5.6)$ & 0.198 \\
\hline Cryptosporidiosis & $269(1.6)$ & $387(1.7)$ & $238(1.6)$ & 0.218 \\
\hline Cryptococcosis & $133(1.6)$ & $182(1.8$ & $110(1.8)$ & 0.707 \\
\hline Others & $130(3.3)$ & $175(3.9)$ & $99(3.8)$ & 0.168 \\
\hline \multicolumn{5}{|l|}{ Opportunistic cancer } \\
\hline \multirow[t]{3}{*}{ Kaposi's sarcoma/HHV8 } & $57(0.7)$ & $104(1.0)$ & $48(0.8)$ & 0.052 \\
\hline & \multicolumn{3}{|l|}{ Prevalence } & $p$ value \\
\hline & Age $<30(n=17,872), n(\%)$ & Age $=30-39(n=23,395), n(\%)$ & Age $\geq 40(n=16,935), n(\%)$ & \\
\hline \multicolumn{5}{|l|}{ Early HAART (2004-2008) } \\
\hline \multicolumn{5}{|l|}{ Opportunistic infection } \\
\hline Geohelminths & $5849(32.7)$ & $7690(32.9)$ & $5645(33.3)$ & 0.365 \\
\hline Diarrhoea & $4323(24.2)$ & $6034(25.8)$ & 4555 (26.9) & 0.010 \\
\hline Oral candida & $2919(16.3)$ & $4510(19.3)$ & $3191(18.8)$ & $<0.0001$ \\
\hline Mycobacterium tuberculosis & $3073(17.2)$ & $4366(18.7)$ & $3150(18.6)$ & 0.006 \\
\hline Bacterial pneumonia & $1277(7.1)$ & $1930(8.2)$ & $1331(7.9)$ & 0.009 \\
\hline Genital ulcer & $1850(10.4)$ & $2634(11.3)$ & $1609(9.5)$ & $<0.0001$ \\
\hline Confirmed malaria & $1230(6.9)$ & $1366(5.8)$ & $883(5.2)$ & $<0.0001$ \\
\hline Esoph candida & $1342(7.5)$ & $2309(9.9)$ & $1648(9.7)$ & $<0.0001$ \\
\hline Herpes zoster & $1080(6.0)$ & $1554(6.6)$ & $1106(6.5)$ & 0.407 \\
\hline Cryptosporidiosis & $554(2.6)$ & $823(3.0)$ & $649(3.6)$ & 0.039 \\
\hline Cryptococcosis & $236(1.3)$ & $399(1.7)$ & $286(1.7)$ & 0.011 \\
\hline Others & $464(3.1)$ & $712(3.5)$ & $608(3.8)$ & 0.07 \\
\hline \multicolumn{5}{|l|}{ Opportunistic cancer } \\
\hline \multirow[t]{3}{*}{ Kaposi's sarcoma/HHV8 } & $166(0.9)$ & $290(1.2)$ & $221(1.3)$ & 0.009 \\
\hline & \multicolumn{3}{|l|}{ Prevalence } & p value \\
\hline & Age < $30(n=21,479), n(\%)$ & Age $=30-39(n=23,168), n(\%)$ & Age $\geq 40(n=17,174), n(\%)$ & \\
\hline \multicolumn{5}{|l|}{ Late HAART (2009-2013) } \\
\hline \multicolumn{5}{|l|}{ Opportunistic infection } \\
\hline Geohelminths & $5230(24.3)$ & $5489(23.7)$ & $4119(24.0)$ & 0.598 \\
\hline Diarrhoea & $3153(14.7)$ & $3352(14.5)$ & $2372(13.8)$ & 0.025 \\
\hline Oral candida & $1442(6.7)$ & $1748(7.5)$ & $1305(7.6)$ & 0.015 \\
\hline Mycobacterium tuberculosis & $1194(5.6)$ & $1423(6.1)$ & $911(5.3)$ & 0.008 \\
\hline Bacterial pneumonia & $1481(6.9)$ & $1601(6.9)$ & $1218(7.1)$ & 0.673 \\
\hline Genital ulcer & $1454(6.8)$ & $1479(6.4)$ & $827(4.8)$ & $<0.0001$ \\
\hline Confirmed malaria & $934(4.3)$ & $896(3.9)$ & $524(3.1)$ & $<0.0001$ \\
\hline Esoph candida & $595(2.8)$ & $662(2.9)$ & $492(2.9)$ & 0.958 \\
\hline
\end{tabular}


Table 4 continued

\begin{tabular}{|c|c|c|c|c|}
\hline & \multicolumn{3}{|l|}{ Prevalence } & \multirow[t]{2}{*}{$p$ value } \\
\hline & Age $<30(n=21,479), n(\%)$ & Age $=30-39(n=23,168), n(\%)$ & Age $\geq 40(n=17,174), n(\%)$ & \\
\hline Herpes zoster & $775(3.6)$ & $856(3.7)$ & $670(3.9)$ & 0.069 \\
\hline Cryptosporidiosis & $228(1.7)$ & $259(1.7)$ & $204(2.2)$ & 0.027 \\
\hline Cryptococcosis & $113(0.5)$ & $178(0.8)$ & $124(0.7)$ & 0.010 \\
\hline Others & $362(1.1$ & $405(1.1)$ & $374(1.2)$ & 0.973 \\
\hline \multicolumn{5}{|l|}{ Opportunistic cancer } \\
\hline Kaposi's sarcoma/HHV8 & $86(0.4)$ & $132(0.6)$ & $91(0.5)$ & 0.055 \\
\hline
\end{tabular}

HHV8 human herpes virus $8, n$ number of patients

accelerate the progression of HIV infection to AIDS [74, 77-80] and were found associated with increased risk for mother-to child-transmission of HIV [60].

Globally, it is estimated that about two billion people are infected with geohelminths mainly in resource limited settings [75]. These infections are however, often neglected in national programmes and yet they exact the greatest burden on limited resources in these settings [75]. They are commonly associated with settings characterised by poor sanitation and poor personal hygiene. Thus in most sub-Saharan Africa, the burden of helminthic infections is still enormous because of the poor sanitation and unhygienic conditions in these settings [81, 82].

However there were contradicting reports on the magnitude of helminthic infections among HIV/AIDS patients in resource poor settings. Some studies have shown higher prevalence of helminthic infections in HIV positive individuals compared to HIV negative controls $[83,84]$. In contrast, others showed no significant difference in prevalence of helminthic infections between HIV positive patients and HIV negative controls [85, 86]. While others showed low prevalence of helminthic infections among HIV positive patients compared to HIV negative controls [87-89]. A number of studies have also shown that the patterns of individual helminthic parasites may differ among HIV positive and HIV negative patients. A study in Honduras found a strong association between S. stercoralis and HIV infection but lower risk for A. lumbricoides and Trichuris trichurias [90]. Another study found a high prevalence of Strongyloidiasis among HIV-positive patients compared to HIV negative controls in Brazil [91]. A related study in Ethiopia also found higher prevalence of $S$. stercoralis among HIV-positive patients with CD4 count $<200$ cells $/ \mu \mathrm{l}$ [83].

In the current study, we were unable to assess this variation in intensity of infection by helminthic infection but we established that the prevalence of helminthic infections generally remained relatively higher compared to other opportunistic infections among HIV positive patients in Uganda even after HAART. However, more studies are required to have more insight on the role of HAART and age on severity of infection due to the different helminthic infections.

In the current study, it was also established that prevalence of geohelminths was lower among men compared to women and higher in older age groups ( $>35$ years). We also observed variation in geographical distribution of geohelminths with Northern and Eastern Uganda having relatively higher burden of geohelminths than Central and Western Uganda. This variation in geographical distribution of geohelminths could be influenced by environmental and socio-economic factors including poverty, poor sanitation and personal hygiene, ignorance, lack of clean water and poor quality health care. In absence of vaccination, the recommended public health interventions would be regular deworming backed by access to clean water, improved sanitation and health education. A Cochrane systematic review of published literature on testing and treating HIV positive patients for intestinal helminthic infections showed that regular deworming with a single dose of albendazole is feasible in resource poor settings and would potentially improve survival and the quality of life of persons living with HIV/AIDs [75]. It is therefore important that regular deworming becomes an integral part of comprehensive HIV/AIDS care in Uganda and other countries in similar settings.

One of the limitations of this study was the fact that we used secondary data which had been collected not primarily for research purposes. Therefore, some variables which would have been useful in interpretation of our results, like patients' viral loads, monitoring CD4 counts, BMI or ART adherence were missing for majority of the patients. These data should be targeted in prospective cohort studies in the future. Secondly, data from the four purposively selected HIV clinics used for this study may have not have been representative of all HIV positive individuals in Uganda which means generalisability could be limited to TASO programme in Uganda. Another limitation was that CD4 
Table 5 Chi squared test for the difference in Ol prevalence by geographical location

\begin{tabular}{|c|c|c|c|c|c|c|}
\hline & \multicolumn{5}{|l|}{ Prevalence } & \multirow[t]{2}{*}{$p$ value } \\
\hline & $\begin{array}{l}\text { Tororo (Eastern Uganda) } \\
(\mathrm{n}=6534), \mathrm{n}(\%)\end{array}$ & \multicolumn{2}{|c|}{$\begin{array}{l}\text { Mulago (Central Uganda) } \\
(\mathrm{n}=7243), \mathrm{n}(\%)\end{array}$} & \multicolumn{2}{|c|}{$\begin{array}{l}\text { Mbarara (South-western } \\
\text { Uganda) }(n=10,586), n(\%)\end{array}$} & \\
\hline \multicolumn{7}{|l|}{ Before HAART (2001-2003) } \\
\hline \multicolumn{7}{|l|}{ Opportunistic infection } \\
\hline Geohelminths & $2671(40.9)$ & \multicolumn{2}{|l|}{$1406(19.4)$} & \multicolumn{2}{|c|}{$2378(22.5)$} & $<0.0001$ \\
\hline Diarrhoea & $2817(43.1)$ & \multicolumn{2}{|l|}{$1780(24.6)$} & \multicolumn{2}{|c|}{$2862(27.0)$} & $<0.0001$ \\
\hline Oral candida & $1531(23.4)$ & \multicolumn{2}{|l|}{$2345(32.4)$} & \multicolumn{2}{|c|}{$4560(43.1)$} & $<0.0001$ \\
\hline Bacterial pneumonia & $858(13.1)$ & \multicolumn{2}{|l|}{$896(12.4)$} & \multicolumn{2}{|c|}{$983(9.3)$} & $<0.0001$ \\
\hline $\begin{array}{l}\text { Mycobacterium tuber- } \\
\text { culosis }\end{array}$ & $830(12.7)$ & \multicolumn{2}{|l|}{$875(12.1)$} & \multicolumn{2}{|c|}{$608(5.7)$} & $<0.0001$ \\
\hline Genital ulcer & $508(7.8)$ & \multicolumn{2}{|l|}{$697(9.6)$} & $658(6$ & & $<0.0001$ \\
\hline Confirmed malaria & $1072(16.4)$ & $826(11.4)$ & & $1771(1$ & 6.7) & $<0.0001$ \\
\hline Esoph candida & $261(4.0)$ & $732(10.1)$ & & $1194(1$ & 1.3) & $<0.0001$ \\
\hline Herpes zoster & $388(5.9)$ & $423(5.8)$ & & $618(5$ & & 0.098 \\
\hline Cryptosporidiosis & $178(2.7)$ & $283(3.9)$ & & $434(4$ & & $<0.0001$ \\
\hline Cryptococcosis & $160(2.4)$ & $145(2.0)$ & & $122(1$ & & $<0.0001$ \\
\hline Others & $75(1.1)$ & $204(2.8)$ & & $112(1$ & & $<0.0001$ \\
\hline Opportunistic cancer & & & & & & \\
\hline Kaposi's sarcoma/HHV8 & $96(1.5)$ & $61(0.8)$ & & $52(0$ & & $<0.0001$ \\
\hline & Prevalence & & & & & $\mathrm{p}$ value \\
\hline & $\begin{array}{l}\text { Tororo (Eastern Uganda) } \\
(n=16,207) \\
n(\%)\end{array}$ & $\begin{array}{l}\text { Mulago (Central } \\
\text { Uganda) }(n=16,288) \\
\text { n (\%) }\end{array}$ & $\begin{array}{l}\text { Mbarara (\$ } \\
\text { Uganda) (r } \\
\text { n (\%) }\end{array}$ & $\begin{array}{l}\text { Nestern } \\
\text { 047), }\end{array}$ & $\begin{array}{l}\text { Gulu (Northern Uganda) } \\
(\mathrm{n}=10,464), \mathrm{n}(\%)\end{array}$ & \\
\hline Early HAART (2004-2008) & & & & & & \\
\hline Opportunistic infection & & & & & & \\
\hline Geohelminths & 5825 (35.9) & $4363(26.8)$ & $4925(28.9)$ & & $3950(37.7)$ & $<0.0001$ \\
\hline Diarrhoea & $4503(27.8)$ & $3261(20.0)$ & $3431(20.1)$ & & $3848(36.8)$ & $<0.0001$ \\
\hline Oral candida & $1966(12.1)$ & $3632(22.3)$ & $4097(24.0)$ & & $976(9.3)$ & $<0.0001$ \\
\hline $\begin{array}{l}\text { Mycobacterium tuber- } \\
\text { culosis }\end{array}$ & $2958(18.2)$ & $3589(22.1)$ & $1936(11.4)$ & & $2198(21.0)$ & $<0.0001$ \\
\hline Bacterial pneumonia & $1301(8.0)$ & $1627(10.0)$ & $823(4.8)$ & & $829(7.9)$ & $<0.0001$ \\
\hline Genital ulcer & $1373(8.5)$ & $2046(12.6)$ & $1474(8.6)$ & & $1229(11.7)$ & $<0.0001$ \\
\hline Confirmed malaria & $893(5.5)$ & $984(6.0)$ & $611(3.6)$ & & $1105(10.6)$ & $<0.0001$ \\
\hline Esoph candida & $969(6.0)$ & $1744(10.7)$ & $1714(10.1)$ & & $901(8.6)$ & $<0.0001$ \\
\hline Herpes zoster & $1103(6.8)$ & $1110(6.8)$ & $970(5.7)$ & & $575(5.5)$ & $<0.0001$ \\
\hline Cryptosporidiosis & $666(4.1)$ & $467(2.9)$ & $419(2.5)$ & & $483(4.6)$ & $<0.0001$ \\
\hline Cryptococcosis & $238(1.5)$ & $337(2.1)$ & $197(1.2)$ & & $162(1.5)$ & $<0.0001$ \\
\hline Others & $364(2.2)$ & $647(4.0)$ & $333(2.0)$ & & $455(4.3)$ & $<0.0001$ \\
\hline Opportunistic cancer & & & & & & \\
\hline Kaposi's sarcoma/HHV8 & $209(1.3)$ & $195(1.2)$ & $128(0.8)$ & & $145(1.4)$ & 0.003 \\
\hline & Prevalence & & & & & p value \\
\hline & $\begin{array}{l}\text { Tororo (Eastern Uganda) } \\
(\mathrm{n}=14,658), \mathrm{n}(\%)\end{array}$ & $\begin{array}{l}\text { Mulago (Central } \\
\text { Uganda) }(n=17,977), \\
\text { n (\%) }\end{array}$ & $\begin{array}{l}\text { Mbarara (S } \\
\text { Uganda) ( }\end{array}$ & $\begin{array}{l}\text { vestern } \\
\text {, } \mathrm{n}(\%)\end{array}$ & $\begin{array}{l}\text { Gulu (Northern Uganda) } \\
(n=15,152), n(\%)\end{array}$ & \\
\hline Late HAART (2009-2013) & & & & & & \\
\hline Opportunistic infection & & & & & & \\
\hline Geohelminths & $3270(22.3)$ & $3373(18.8)$ & $3169(21.0)$ & & $3991(26.3)$ & $<0.0001$ \\
\hline Diarrhoea & 2786 (19.0) & 1949 (10.8) & $1653(11.0)$ & & $2585(17.1)$ & $<0.0001$ \\
\hline Oral candida & $731(5.0)$ & $1822(10.1)$ & $1617(10.7)$ & & $339(2.2)$ & $<0.0001$ \\
\hline
\end{tabular}


Table 5 continued

\begin{tabular}{|c|c|c|c|c|c|}
\hline & \multicolumn{4}{|l|}{ Prevalence } & \multirow[t]{2}{*}{ p value } \\
\hline & $\begin{array}{l}\text { Tororo (Eastern Uganda) } \\
(\mathrm{n}=14,658), \mathrm{n}(\%)\end{array}$ & $\begin{array}{l}\text { Mulago (Central } \\
\text { Uganda) }(\mathrm{n}=17,977), \\
\mathrm{n}(\%)\end{array}$ & $\begin{array}{l}\text { Mbarara (South western } \\
\text { Uganda) }(15,095), n(\%)\end{array}$ & $\begin{array}{l}\text { Gulu (Northern Uganda) } \\
(\mathrm{n}=15,152), \mathrm{n}(\%)\end{array}$ & \\
\hline Bacterial pneumonia & $1354(9.2)$ & $1043(5.8)$ & $641(4.2)$ & $1310(8.6)$ & $<0.0001$ \\
\hline $\begin{array}{l}\text { Mycobacterium tuber- } \\
\text { culosis }\end{array}$ & $780(5.3)$ & $1088(6.1)$ & $436(2.9)$ & $1286(8.5)$ & $<0.0001$ \\
\hline Genital ulcer & $767(5.2)$ & $1047(5.8)$ & $1265(8.4)$ & $704(4.6)$ & $<0.0001$ \\
\hline Confirmed malaria & $769(5.2)$ & $688(3.8)$ & $365(2.4)$ & $562(3.7)$ & $<0.0001$ \\
\hline Esoph candida & $342(2.3)$ & $640(3.6)$ & $489(3.2)$ & $286(1.9)$ & $<0.0001$ \\
\hline Herpes zoster & $581(4.0)$ & $739(4.1)$ & $554(3.7)$ & $396(2.6)$ & $<0.0001$ \\
\hline Cryptosporidiosis & $219(1.5)$ & $198(1.1)$ & $140(0.9)$ & $138(0.9)$ & 0.011 \\
\hline Cryptococcosis & $198(1.4)$ & $96(0.5)$ & $56(0.4)$ & $67(0.4)$ & $<0.0001$ \\
\hline Others & $356(2.4)$ & $351(2.0)$ & $239(1.6)$ & $203(1.3)$ & $<0.0001$ \\
\hline \multicolumn{6}{|l|}{ Opportunistic cancer } \\
\hline Kaposi's sarcoma/HHV8 & $116(0.8)$ & $91(0.5)$ & $58(0.4)$ & $45(0.3)$ & $<0.0001$ \\
\hline
\end{tabular}

HHV8 human herpes virus $8, n$ number of patient

cell evaluations were not available for most patients and yet the study would have been be more informative if the rates of OI were reviewed in the context of CD4 cell counts. Thirdly, some OIs were not captured in the data base probably because of inadequate diagnostic capacity. Additionally, improvements in OI diagnosis like introduction of the lateral flow cryptococcal Antigen $(\mathrm{CrAg})$ rapid tests for Cryptococcal meningitis and Gene Xpert for TB over time may have had an impact on prevalence of these OIs. Fourthly, cryptococcal meningitis and Kaposi's prevalences could have been underestimated due to the fact they are referral conditions and the study clinics only handled out patients, so need to be interpreted with caution. Lastly the data presented doesn't prove that HAART is responsible for the shift in OIs. However, we believe HAART greatly contributed to the reduction in the frequency of OIs, though it may not necessarily be the only factor. Other factors like general improvements in the quality of care and availability of more potent treatment drugs (fluconazole, etc.), antimicrobial prophylaxis and general improvement in socio-economic status over time could have also contributed to the overall reduction in the prevalence of OIs.

\section{Conclusions}

Results from the current study show that the frequency and patterns of OIs have changed since the introduction of HAART in Uganda. However, these changes varied by type of OI, time period, age, gender and geographical location of the HIV positive patient. Geohelminths and diarrheal infection $<1$ month remains a challenge even after HAART and should therefore be given special attention in
HIV/AIDS care programmes in these settings. Our findings further shows that opportunistic infections rather than opportunistic cancers were the primary cause of morbidity accounting for $99 \%$ of all the opportunistic episodes among HIV positive patients in these settings. However compared to other geographical areas in Uganda, HIV positive patients in Northern and Eastern Uganda bore the highest burden of OIs both before and after HAART and therefore should be given special consideration in terms of resource allocation and targeted interventions so as to reduce the disease burden due to OIs in these areas.

\section{Abbreviations}

HAART: highly active antiretroviral therapy; HIV: human immunodeficiency virus; IQR: interquartile range; IRB: Institutional Review Board; AIDS: acquired immunodeficiency syndrome; Ol: opportunistic infection; TASO: The AIDS Support Organisation; UNAIDS: Joint United Nations Programme on HIV/AIDS; WHO: World Health Organisation; SDG: sustainable development goal.

\section{Authors' contributions}

JR conceived the study, participated in the study design, data collection, analysis and manuscript writing; NMT, JKL participated in study design, data analysis and manuscript writing; HW, ENJ, FM participated in study design and manuscript writing; All authors read and approved the final manuscript.

\section{Author details}

${ }^{1}$ Department of Epidemiology and Biostatistics, School of Public Health, College of Health Sciences, Makerere University, Kampala, Uganda. ${ }^{2}$ Department of Public Health, School of Health Sciences, Mountains of the Moon University, P.O. Box 837, Fort Portal, Uganda.

\section{Acknowledgements}

The authors are grateful to the AIDS Support Organization (TASO) in Uganda for providing the data and Mountains of the Moon University for all the support towards this study.

\section{Competing interests}

The authors declare that they have no competing interests. 


\section{Availability of data and materials}

All relevant data generated or analyzed during this study are included in this manuscript.

\section{Ethical approval and consent to participate}

The study obtained ethical approval from Makerere University School of Public Health Higher Degrees Research and Ethics committee (No. IRB00011353) and the Uganda National Council for Science and Technology (No. HS895). The above ethical committees waived off the need for consent to participate since this was secondary data analysis.

Received: 9 March 2016 Accepted: 1 December 2016

Published online: 07 December 2016

\section{References}

1. UNAIDS. Global AIDS update 2016. Geneva: WHO/UNAIDS; 2016.

2. WHO. HIV/AIDS facts sheet. Geneva: WHO; 2015.

3. Kaplan JE, Hu DJ, Holmes KK, Jaffe HW, Masur H, De Cock KM. Preventing opportunistic infections in human immunodeficiency virus-infected persons: implications for the developing world. Am J Trop Med Hyg. 1996;55(1):1-11

4. Holmes B, Losina E, Walensky R, Yazdanpanah Y, Freedberg K. Review of human immunodeficiency virus type 1-related opportunistic infections in Sub-Saharan Africa. Clin Infect Dis. 2003:36:652-62.

5. Mermin J, Were W, Ekwaru J, Moore D, Dawning R, Behumbiize P, Lule JR, Coutinho A, Tappero J, Bunnell R. Mortality in HIV-infected Ugandan adults receiving antiretroviral treatment and survival of their HIV-uninfected children: a prospective cohort study. Lancet. 2008;371:752-9.

6. Staine JG. AIDS up date 2007: an overview of acquired immune deficiency syndrome. New York: McGraw-Hill co., Inc; 2008.

7. Chaisson R, Moore R. Prevention of opportunistic infections in the era of improved antiretroviral therapy. J Acquir Immune Defic Syndr 1997;16:S14-22.

8. Colebunders R, Latif AS. Natural history and clinical presentation of HIV-1 infection in adults. AIDS. 1991:5:S103-12.

9. Selik MR, Starcher ET, Curran JW. Opportunistic diseases reported in AIDS patients: frequencies, associations and trends. AIDS. 1987;1:175-82.

10. Paton NI, Sangeetha S, Earnest A, Bellamy R. The impact of malnutrition on survival and the CD4 count response in HIV-infected patients starting antiretroviral therapy. HIV Med. 2006;7:323-30.

11. UNAIDS. UNAIDS report on the global AIDS epidemic 2013. Geneva: UNAIDS: 2013.

12. Brooks J, Kaplan J, Holmes K, Benson C, Pau A, Masur H. HIV-associated opportunistic infections-going, going, but not gone: the continued need for prevention and treatment guidelines. Clin Infect Dis. 2009:48(5):609-11.

13. Bonnet F, Lewden C, May T, Heripret C, Jougla E, Bevilacqua S, Costagliola D, Salmon D, Chene G, Morlat P. Opportunistic infections as cause of death in HIV infected patients in the HAART era in France. Scand J Infect Dis. 2005:37:482-7.

14. Corey DM, Kim HW, Salazar R, Illescas R, Villena J, Gutierrez L, Sanchez J, Tabet SR. Brief report: effectiveness of combination antiretroviral therapy on survival and opportunistic infections in a developing world setting: an observational cohort study. J Acquir Immune Defic Syndr. 2007:44:451-5.

15. Sun HY, Chen MY, Hsieh SM, Sheng WH, Chang SY, Hsiao CF, Hung CC, Chang SC. Changes in the clinical spectrum of opportunistic illnesses in persons with HIV infection in the era of highly active antiretroviral therapy. Jpn J Infect Dis. 2006;59:311-6.

16. Manosuthi W, Chaovavanich A, Tansphaswadikul S, Prasithsirikul W, Inthong Y, Chottanapund S, Sittibusaya C, Moolasart V, Termvises P, Sungkanuparph S. Incidence and risk factors of major opportunistic infections after initiation of antiretroviral therapy among advanced HIV infected patients in a resource-limited setting. J Infect. 2007;55:464-9.

17. Moges N, Kassa M. Prevalence of opportunistic infections and associated factors among HIV positive patients taking anti-retroviral therapy in DebreMarkos Referral Hospital, Northwest Ethiopia. J AIDS Clin Res. 2014;5:301.

18. Uganda Ministry of Health. National AIDS indicator survey 2011. Kampala: Uganda Ministry Of Health; 2011.
19. WHO. Scaling up antiretroviral therapy in resource limited settings (treat 3 million by 2005): treatment guidelines for a public health approach 2003 revision. Geneva: WHO; 2004

20. WHO. Antiretroviral therapy for HIV infection in adults and adolescents; recommendations for a public health approach. Geneva: WHO; 2006.

21. WHO. Antiretroviral therapy for HIV infection in adults and adolescents: recommendations for a public health approach 2010 revision. Geneva: WHO; 2010

22. Uganda Ministry of Health. Antiretroviral treatment policy. Kampala: Uganda Ministry of Health; 2009

23. TASO Services and Programmes. http://www.tasouganda.org/. Accessed 21 Mar 2015.

24. WHO/UNAIDS. WHO case definition of HIV for surveillance and revised clinical staging and immunological classification of HIV-related disease in adults and children. Geneva: WHO; 2006

25. Paradžik $M$, Bučević-Popović $V$, Šitum M, Jaing C, Degoricija M, McLoughlin K, Ismail S, Punda-Polić $V$, Terzić J. Association of Kaposi's sarcomaassociated herpesvirus (KSHV) with bladder cancer in Croatian patients. Tumour Biol. 2014;35(1):567-72

26. Theuring S, Mugeny K, Rubaihayo J, Busingye P, Harms G. Antiretroviral therapy programme retention and outcomes after 12 months in a retrospective patient cohort in Fort Portal, Uganda: the ongoing challenge of male ART performance. AIDS Clin Res. 2015;6:423.

27. Mageda K, Leyna G, Mmbaga E. High initial HIV/AIDS-related mortality and-its predictors among patients on antiretroviral therapy in the Kagera region of Tanzania: a five-year retrospective cohort study. AIDS Research and Treatment. 2012:2012:1-7.

28. Iroezindu M, Ofondu E, Hausler H, Van Wyk B. Factors for opportunistic infections in HIV patients receiving antiretroviral therapy in a resourcelimited setting in Nigeria. J AIDS Clin Res. 2013;S3:002.

29. Devi S, Ningshen R, Arvind G. Burden of opportunistic infections in hiv/ aids patients in the highly active antiretroviral therapy era: a regional institute of medical sciences, Imphal perspective. In: Munjal Y, editor. API text book of Medicine. Kolkata: The Association of Physicians of India; 2013.

30. Misra S, Sengupta D, Satpathy S. AIDS in India: recent trends in opportunistic infections. Southeast Asian J Trop Med Public Health. 1998;29(2):373-6.

31. Damtie D, Yismaw G, Woldeyohannes D, Anagaw B. Common opportunistic infections and their CD4 cell correlates among HIV-infected patients attending at antiretroviral therapy clinic of Gondar University Hospital, Northwest Ethiopia. BMC Res Notes. 2013;6(1):534.

32. Mitiku H, Weldegebreal F, Teklemariam Z. Magnitude of opportunistic infections and associated factors in HIV-infected adults on antiretroviral therapy in eastern Ethiopia. HIV/AIDS. 2015:7:137-44.

33. Jougla E, Pequignot F, Carbon C, Pavillon G, Eb M, Bourdais JP, Bourdais O, Hatton F. AIDS-related conditions: study of a representative sample of 1203 patients deceased in 1992 in France. Int J Epidemiol. 1996;25:190-7.

34. Skalsky J, Ndumbe PM. Characteristics of HIV/AIDS patients attending a rural hospital in Cameroon. Ann Soc Belg Med Trop. 1993;73:209-16.

35. Ndour M, Sow PS, Coll-Seck AM, Badiane S, Ndour CT, Diakhate N, Diop B, Faye M, Soumare M, Diouf G, et al. AIDS caused by HIV1 and HIV2 infection: are there clinical differences? Results of AIDS surveillance 1986-97 at Fann Hospital in Dakar, Senegal. Trop Med Int Health. 2000;5(10):687-91.

36. Chakraboty N, Mukherjee A, Santra S, Sarkar RN, Banerjee D, Guha SK, Chakraboty S, Bhattacharyya SK. Current trends of opportunistic infections among HIV sero-positive patients from Eastern India. Jpn J Infect Dis. 2008:61:49-53.

37. Saldanha D, Gupta N, Shenoy S, Saralaya V. Prevalence of opportunistic infections in AIDS patients in Mangalore, Karnataka. Trop Doct. 2008:38:172-3.

38. Sok P, Harwell Jl, McGarvey ST, Lurie M, Lynen L, Flanigan T, Mayer KH. Demographic and clinical characteristics of HIV infected in-patients and out-patients at a Cambodian hospital. AIDS Patients Care STDs. 2006;20(5):369-78.

39. Malamba SS, Morgan D, Clayton T, Mayanja B, Okongo M, Whitworth J. The prognostic value of the WHO staging system for HIV infection and disease in rural Uganda. AIDS. 1999;13:2555-62.

40. Spacek LA, Shihab H, Kamya M, Mwesigire D, Ronald A, Mayanja H, Moore D, Bates M, Quinn TC. Response to antiretroviral therapy in HIV-infected patients attending a public, urban clinic in Kampala, Uganda. Clin Infect Dis. 2006:42:252-9. 
41. Morgan D, Mahe C, Mayanja B, Whitworth JA. Progression to symptomatic disease in people infected with HIV-1 in rural Uganda: prospective cohort study. BMJ. 2002;324:193-6.

42. MacArthur R, DuPont H. Etiology and pharmacologic management of noninfectious diarrhea in HIV-infected individuals in the highly active antiretroviral therapy era. Clin Infect Dis. 2012;55(6):860-7.

43. Guest J, Ruffin C, Tschampa J, DeSilva K, Rimland D. Differences in rates of diarrhea in patients with human immunodeficiency virus receiving lopinavir-ritonavir or nelfinavir. Pharmacotherapy. 2004;24(6):727-35.

44. Johnson M, Grinsztejn B, Rodriguez C, Coco J, DeJesus E, Lazzarin A, Lichtenstein K, Wirtz V, Rightmire A, Odeshoo L, et al. 96-week comparison of once-daily atazanavir/ritonavir and twice-daily lopinavir/ritonavir in patients with multiple virologic failures. AIDS. 2006;20(5):711-8.

45. Heiser C, Ernst J, Barrett J, French N, Schutz M, Dube M. Probiotics, soluble fiber and L-glutamine (GLN) reduce nelfinavir (NFV) or lopinavir/ritonavir (LPV/r)-related diarrhea. J Int Assoc Physicians AIDS Care. 2004;3:121-9.

46. Molina J, Andrade-Villanueva J, Echevarria J, Chetchotisakd P, Corral J, David N, Moyle G, Mancini M, Percival L, Yang R, et al. Once-daily atazanavir/ritonavir versus twice-daily lopinavir/ritonavir, each in combination with tenofovir and emtricitabine, for management of antiretroviral-naive HIV-1-infected patients: 48 week efficacy and safety results of the CASTLE study. Lancet. 2008:372(9639):646-55.

47. Binka A, Mahe C, Watera C, Lugada E, Gilks CF, Whitworth JAG, French N. Diarrhoea, CD4 counts and enteric infections in a community-based cohort of HIV-infected adults in Uganda. J Infect. 2002;45(2):99-105.

48. WHO. Global tuberculosis control report 2013. Geneva: WHO; 2013.

49. Selwyn A, Hartel D, Lewis VA, Schoenbaum E, Vermund S, Klein R, Walker $A$, Friedland $G$. A prospective study of the risk of tuberculosis among intravenous drug users with human immunodeficiency virus infection. N Engl J Med. 1989;320(9):545-50.

50. Holmes C, Hausler $H$, Nunn P. A review of sex differences in the epidemiology of tuberculosis. Int J Tuberc Lung Dis. 1998;2(2):96-104.

51. Borgdorff M, Nagelkerke N, Dye C, Nunn P. Gender and tuberculosis: a comparison of prevalence surveys with notification data to explore sex differences in case detection. Int J Tuberc Lung Dis. 2000;4(2):123-32.

52. Moore D, Liechty C, Ekwaru P, Were W, Mwima G, Solberg P, Rutherford G, Mermin J. Prevalence, incidence and mortality associated with tuberculosis in HIV-infected patients initiating antiretroviral therapy in rural Uganda. AIDS. 2007;21(6):713-9

53. WHO. Global tuberculosis report 2015. 20th ed. Geneva: WHO; 2015.

54. French N, Nakiyingi J, Carpenter L, Lugada E, Moi K, Watera C, Moore M, Antvelink L, Mulder D, Janoff E, et al. 23-Valent pneumococcal polysaccharide vaccine in HIV-1-infected Ugandan adults: double-blind, randomised and placebo controlled trial. Lancet. 2000;355(9221):2106-11.

55. Gilks CF, Ojoo SA, Ojoo JC, Brindle RJ, Paul J, Batchelor BI, Kimari JN, Newnham R, Bwayo J, Plummer FA, et al. Invasive pneumococcal disease in a cohort of predominantly HIV-1 infected female sex-workers in Nairobi, Kenya. Lancet. 1996;347(9003):718-23.

56. Miiro G, Kayhty H, Watera C, Tolmie H, Whitworth J, Gilks C, French N. Conjugate pneumococcal vaccine in HIV-infected Ugandans and the effect of past receipt of polysaccharide vaccine. J Infect Dis. 2005;192(10):1801-5.

57. Benito N, Moreno A, Miro JM, Torres A. Pulmonary infections in HIV-infected patients: an update in the 21st century. Eur Respir J. 2012;39:730-45.

58. WHO. Soil-transmitted helminth infections: facts sheet. Geneva: WHO media centre; 2015

59. WHO. WHO guidelines for the treatment of malaria. 3rd ed. Geneva: WHO; 2015. p. 55.

60. Gallagher M, Malhotra I, Mungai P, Wamachi A, Kioko J, Ouma J, Muchiri E, King C. The effects of maternal helminth and malaria infections on mother-to-child HIV transmission. AIDS. 2005;19(16):1849-55.

61. Ivan E, Crowther N, Rucogoza A, Osuwat L, Munyazesa E, Mutimura E, Njunwa K, Zambezi K, Grobusch M. Malaria and helminthic co-infection among HIV-positive pregnant women: prevalence and effects of antiretroviral therapy. Acta Trop. 2012;124(3):179-84.

62. WHO. WHO case definitions of HIV for surveillance and revised clinical staging and immunological classification of HIV-related diseases in adults and children. Geneva:WHO; 2006

63. Whitworth J, Morgan D, Quigley M, Smith A, Mayanja B, Eotu H, Omoding N, Okongo M, Malamba S, Amato Ojwiya A. Effect of HIV-1 and increasing immunosuppression on malaria parasitaemia and clinical episodes in adults in rural Uganda: a cohort study. Lancet. 2000;356(9235):1051-6.

64. Verhoeff F, Brabin J, Hart C, Chimsuku L, Kazembe P, Broadhead R. Increased prevalence of malaria in HIV-infected pregnant women and its implications for malaria control. Trop Med Int Health. 1999;4(1):5-12.

65. Herrero M, Rivas P, Rallón N, Ramírez-Olivencia G, Puente S. HIV \& Malaria. AIDS Rev. 2007:9:88-98.

66. Kamya R, Rosenthal P, Gasasira A, Dorsey G, Yeka A, Havlir D. Effect of HIV-1 infection on antimalarial treatment outcomes in Uganda: a population-based study. J Infect Dis. 2006;193:9-15.

67. Francesconi P, Fabiani M, Dente M, Lukwiya M, Okwey R, Ouma J, Ochakachon R, Cian F, Declich S. HIV, malaria parasites, and acute febrile episodes in Ugandan adults: a case-control study. AIDS. 2001;15(18):2445-50.

68. French N, Nakiyingi J, Lugada E, Watera C, Whitworth J, Gilks C. Increasing rates of malarial fever with deteriorating immune status in HIV-1-infected Ugandan adults. AIDS. 2001;15:899-906.

69. WHO. World malaria report 2014. Geneva: WHO; 2014.

70. Chandramohan D, Greenwood B. Is there an interaction between human immunodeficiency virus and Plasmodium falciparum? Int J Epidemiol. 1998:27:296-301.

71. Goselle O, Onwuliri C, Onwuliri V. Malaria infection in HIV/AIDS patients and its correlation with packed cell volume (PCV). J Vector Borne Dis. 2009:46:205-11.

72. Smith T, Hurt N, Teuscher T, Tanner M. Is fever a good clinical sign of malaria in surveys of endemic communities? Am J Trop Med Hyg. 1995;52:306-10.

73. Cohen C, Karstaedt A, Frean J, Thomas J, Govender N, Prentice E, Dini L, Galpin J, Crewe-Brown H. Increased prevalence of severe malaria in HIVinfected adults in South Africa. Clin Infect Dis. 2005:41(11):1631-7.

74. Idindili B, Jullu B, Hattendorfi J, Mugusi F, Antelman G, Tanner M. HIV and parasitic co-infections among patients seeking care at health facilities in Tanzania. Tanzan J Health Res. 2011;13(4):75-85.

75. Alexander P, De P. HIV-1 and intestinal helminth review update: updating a Cochrane Review and building the case for treatment and has the time come to test and treat? Parasite Immunol. 2009;31:283-6.

76. Woodburn P, Muhangi L, Hillier S, Ndibazza J, Namujju P, Kizza M, Ameke C, Omoding N, Booth M, Elliott A, et al. Risk factors for helminth, malaria, and HIV infection in pregnancy in Entebbe, Uganda. PLoS Negl Trop Dis. 2009;3:e473.

77. Borkow G, Bentwich Z. HIV and helminth co-infection: is deworming necessary? Parasite Immunol. 2006;28:605.

78. Nissapatorn V, Sawangjaroen N. Parasitic infections in HIV infected individuals: diagnostic \& therapeutic challenges. Indian J Med Res. 2011;134:878.

79. Brown M, Mawa P, Kaleebu P, Elliott A. Helminths and HIV infection: epidemiological observations on immunological hypotheses. Parasite Immunol. 2006;28:613-23.

80. Webb E, Ekii A, Pala P. Epidemiology and immunology of helminth-HIV interactions. Curr Opin HIV AIDS. 2012;7:245-53.

81. Walson J, Stewart B, Sangare L, Mbogo L, Otieno P, Piper B, Richardson B, Stewart J. Prevalence and correlates of helminth co-infection in Kenyan HIV-1 infected adults. PLoS Negl Trop Dis. 2010;4(3):e644.

82. Knopp S, Mgeni A, Khamis I, Steinmann P, Stothard J, et al. Diagnosis of soil-transmitted helminths in the era of preventive chemotherapy: effect of multiple stool sampling and use of different diagnostic techniques. PLoS Negl Trop Dis. 2008;2:e331

83. Assefa S, Erko B, Medhin G, Assefa Z, Shimelis T. Intestinal parasitic infections in relation to HIV/AIDS status, diarrhea and CD4 T-cell count. BMC Infect Dis. 2009:9:155

84. Babatunde S, Salami A, Fabiyi J, Agbede O, Desalu O. Prevalence of intestinal parasitic infestation in HIV seropositive and seronegative patients in Ulorin, Nigeria. Ann Afr Med. 2010;9(3):123-8.

85. Abaver D, Nwobegahay J, Goon D, Iweriebor B, Anye D. Prevalence of intestinal parasitic infections among HIV/AIDS patients from two health institutions in Abuja, Nigeria. Afr Health Sci. 2011;11(Suppl1):S24.

86. Hailemariam G, Kassu A, Abebe G, Abate E, Damte D, Mekonnen E, Ota F. Intestinal parasitic infections in HIV/AIDS and HIV seronegative individuals in a teaching hospital, Ethiopia. Jpn J Infect Dis. 2004:57:41.

87. Taye B, Desta K, Ejigu S, Dori G. The magnitude and risk factors of intestinal parasitic infection in relation to human immunodeficiency virus 
infection and immune status, at ALERT Hospital, Addis Ababa, Ethiopia. Parasitol Int. 2014;2014(63):550-6.

88. Mwambete K, Justin-Temu M, Peter S. Prevalence and management of intestinal helminthiasis among HIV-infected patients at Muhimbili National Hospital. J Int Assoc Physicians AIDS Care. 2010;9:150.

89. Hosseinipour M, Napravnik S, Joaki G, Gama S, Mbeye N, Banda B, Martinson F, Hoffman I, Cohen M. HIV and parasitic infection and the effect of treatment among adult outpatients in Malawi. J Infect Dis. 2007:195:1278
90. Lindo JF, Dubon JM, Age RA, De Gourville EM, Solo-Gabriele H, Klaskala WI, Baum MK, Palmer CJ. Intestinal parasitic infections in human immunodeficiency virus (HIV)-positive and HIV-negative individuals in San Pedro Sula, Honduras. Am J Trop Med Hyg. 1998;58:431-5.

91. Feitosa G, Bandeira AC, Sampaio DP, Badaro R, Brites C. High prevalence of giardiasis and strongyloidiasis among HIV-infected patients in Bahia, Brazil. Braz J Infect Dis. 2001;5:339-44.

\section{Submit your next manuscript to BioMed Central and we will help you at every step:}

- We accept pre-submission inquiries

- Our selector tool helps you to find the most relevant journal

- We provide round the clock customer support

- Convenient online submission

- Thorough peer review

- Inclusion in PubMed and all major indexing services

- Maximum visibility for your research

Submit your manuscript at

www.biomedcentral com/submit 